\title{
Corrigendum
}

\section{All in it Together? Community Food Aid in a Multi-Ethnic Context - CORRIGENDUM}

\author{
MADELEINE POWER, BOB DOHERTY, NEIL SMALL, SIMON TEASDALE \\ AND KATE E. PICKETT
}

doi:10.1017/So047279417000010, first published online by Cambridge University Press, 26 January 2017.

The following acknowledgement was omitted from the original publication:

The authors would like to acknowledge the support of the BBSRC (The Biotechnology and Biosciences Research Council) for the funding of IKnowFood at York which is 4-year research programme being funded through the Global Food Security-Food System Resilience programme with contributions from BBSRC, ESRC, NERC, and the Scottish Government.

The authors apologise for this oversight.

\section{Reference}

Power, M., Doherty, B., Small, N., Teasdale, S. and Pickett, K. E. (2017), All in it Together? Community Food Aid in a Multi-Ethnic Context, Journal of Social Policy, first published online 26 January 2017, doi:10.1017/So047279417000010. 